\title{
Synthesis and Characterization of Ni.Co(OH) 2 Material for Supercapacitor Application
}

\author{
P.E.Lokhande ${ }^{1}$, H. S. Panda ${ }^{2}$ \\ Assistant Professor, Dept. of Mechanical Engineering, Sinhgad Institute of Advanced Technology, Lonavala, India ${ }^{1}$
}

Assistant Professor, Dept. of Materials Engineering, Defence Institute of Advanced Technology, DRDO, Pune, India ${ }^{2}$

\begin{abstract}
Nanosized $\beta-\mathrm{Ni}(\mathrm{OH})_{2}$ is being widely used as an electrode material for supercapacitor because of its high power density, high specific energy and low toxicity. But with addition of dope material like Co, Al specific capacitance of $\mathrm{Ni}(\mathrm{OH}) 2$ significantly increased. $\mathrm{Ni}(\mathrm{OH})_{2}, \mathrm{Co}(\mathrm{OH})_{2}$ and $\mathrm{Ni} . \mathrm{Co}(\mathrm{OH})_{2}$ was successfully synthesized by conventional precipitation method. Developed materials were characterized by using X-ray Diffraction (XRD), Scanning electron microscope (SEM), Atomic Force Microscopy (AFM), Fourier Tranform Infrared Spectroscopy (FTIR). XRD result confirmed the substitution of cobalt in nickel hydroxide. Electrochemical studies were carried out by using cyclic voltammetric $(\mathrm{CV})$. Specific capacitance obtained from $\mathrm{Ni} . \mathrm{Co}(\mathrm{OH})_{2}$ significantly higher than $\mathrm{Ni}(\mathrm{OH})_{2}$ and $\mathrm{Co}(\mathrm{OH})_{2}$ and was found to be $708 \mathrm{~F} / \mathrm{g}$ at scan rate $1 \mathrm{mV} / \mathrm{s}$.
\end{abstract}

Keywords: Supercapaciror; Electrochemical; pseudocapacitor; nanocomposites.

\section{INTRODUCTION}

Supercapacitor, also called electrochemical capacitor or ultracapacitor, is a class of energy storage device similar to a battery. Supercapacitors became a promising candidate for energy storage because of their high power performance, long cycle life and low maintenance cost. ${ }^{1,2}$ It is used as a major power source in hybrid electric vehicle, backup memory power, emergency door of airplane, portable electronics, micro devices etc. Based on the charge storage mechanism, supercapacitor can be classified into electrical double layer capacitor and pseudocapacitor. $^{3,4}$ In electrical double layer capacitor, capacitance arises from charge separation at electrode/electrolyte interface while in case of pseudocapacitor, capacitance arises from fast, reversible faradaic reactions occurring at or near the solid electrode surface. Carbon based materials (activated carbon ${ }^{9}$, carbon nanotubes ${ }^{7}$, carbon aerogels) comes under EDLC while transition metal oxides, hydroxide $\left(\mathrm{RuO}^{5}, \mathrm{MnO}_{2}{ }^{8}\right.$, $\mathrm{Ni}(\mathrm{OH})_{2}{ }^{7}, \quad \mathrm{Co}(\mathrm{OH})_{2}{ }^{9}$ etc.) and conducting polymers (polyaniline) comes under pseudocapacitance.

From material point of view, transition metal oxides and hydroxides plays a vital role in supercapacitor. In transition metal oxides $\mathrm{RuO}_{2}$ is best because of its good electrical conductivity and specific capacitance. ${ }^{10}$ However, it is not widely used owing to its high cost and toxic nature. Therefore other environmentally friendly and cheap material like $\mathrm{Ni}(\mathrm{OH})_{2}$ substitute $\mathrm{RuO} 2 . \mathrm{Ni}(\mathrm{OH})_{2}$ is less expensive and has high theoretical capacitance. This theoretical capacitance can be achieved using some doped element like Al, Co etc. Substitution of cobalt compounds into nickel system increases electronic conductivity while nickel compound in the cobalt system improves electrochemical performance. J. H. Zhong et al. synthesized $\mathrm{Co}_{3} \mathrm{O}_{4} / \mathrm{Ni}(\mathrm{OH})_{2}$ composite mesoporous nanosheet network grown on conductive substrate. ${ }^{11} \mathrm{~J}$. Li et al. reported hydrothermal and chemical deposition combined method for preparation of $\mathrm{Ni}(\mathrm{OH})_{2} / \mathrm{Co}(\mathrm{OH})_{2}$ composite. Specific capacitance obtained from this composite is $1144 \mathrm{~F} / \mathrm{g}$ at scan rate $5 \mathrm{mV} / \mathrm{s} .{ }^{12}$ Novel three dimensional porous nano $\mathrm{Ni} / \mathrm{Co}(\mathrm{OH})_{2}$ nanoflake composite film also used as an electrode for supercapacitor application. Impressively energy density as high as $80 \mathrm{Wh} / \mathrm{kg}$ and power density $11 \mathrm{~kW} / \mathrm{kg}$ were obtained from this $\mathrm{Co}(\mathrm{OH})_{2}$ nanoflakes in the composite film. ${ }^{13}$ A. Audemer et al. did electrochemical and Raman study for beta nickel hydroxide $\mathrm{Ni}_{1-\mathrm{x}} \mathrm{Co}_{\mathrm{x}}(\mathrm{OH})_{2}$ as a electrode material. ${ }^{14}$ Nickel and cobalt hydroxide synthesized by sonochemical method, deposited on ITO electrodes were used as electrodes for supercapacitor application. ${ }^{15} \mathrm{~L}$. Su et al. Studied electrochemical performance of the $\mathrm{Co}(\mathrm{OH})_{2} / \mathrm{Ni}(\mathrm{OH})_{2}$ composite in lithium hydroxide solution. ${ }^{16}$

In this paper we synthesized $\mathrm{Ni}(\mathrm{OH})_{2}, \mathrm{Co}(\mathrm{OH})_{2}$ and $\mathrm{Ni} . \mathrm{Co}(\mathrm{OH})_{2}$ by conventional precipitation method. The specific capacitance of $\mathrm{Ni}(\mathrm{OH})_{2}$ used as a single material is very less than $\mathrm{Co}(\mathrm{OH})_{2}$ and $\mathrm{Ni} . \mathrm{Co}(\mathrm{OH})_{2}$. The significantly improvement of specific capacitance and cyclic stability in case of in case of $\mathrm{Ni} \cdot \mathrm{Co}(\mathrm{OH})_{2}$.

\section{EXPERIMENTAL}

\section{A. Materials and methods}

Synthesis of $\mathrm{Ni}(\mathrm{OH})_{2}: \mathrm{Ni}(\mathrm{OH})_{2}$ was synthesized by the chemical precipitation method. In typical synthesis $2 \mathrm{~g}$ $\mathrm{Ni}\left(\mathrm{NO}_{3}\right)_{2} \cdot 6 \mathrm{H}_{2} \mathrm{O}$ were dissolved in $100 \mathrm{ml}$ of DI water under magnetic stirring. After 15 minutes $1 \mathrm{M} \mathrm{NaOH}$ solution (14ml) were added drop-wise in the above solution to maintain $\mathrm{pH}$ up to 10 . Because of $\mathrm{NaOH}$ addition solution colour changed greenish to faint greenish. This solution was stirred for 2 hours and precipited particles separated using a centrifuge. These particles were washed three-four times with distilled water 
and then kept in oven at $70^{\circ} \mathrm{C}$ for drying purposes for 8 hours. Dry powder is used for making active electrode. Synthesis of $\mathrm{Co}(\mathrm{OH})_{2}$ : In the case of $\mathrm{Co}(\mathrm{OH})_{2}, 2 \mathrm{~g}$ of $\mathrm{Co}\left(\mathrm{NO}_{3}\right)_{2}$ were dissolved in $100 \mathrm{ml}$ DI water under continuous stirring about 15 mimute. After that $1 \mathrm{M}$ $\mathrm{NaOH}$ was added dropwise in the above solution up to $\mathrm{Ph}$ 11 and because of this solution colour changed from reddish to reddish black. Above solution stirred for 2 hours and then particles were separated by using centrifuge also washed three four time by DI water and once ethanol. This precipitate particles dryed in oven at $70^{\circ} \mathrm{C}$ about a 8 hours and in this way blakish coloured powder of $\mathrm{Co}(\mathrm{OH})_{2}$ was synthesized.

Synthesis of Ni.Co(OH $)_{2}$ hybrid: Same procedure was followed in this case, $1 \mathrm{~g} \mathrm{Ni}\left(\mathrm{NO}_{3}\right)_{2} \cdot 6 \mathrm{H}_{2} \mathrm{O}, 1 \mathrm{~g} \mathrm{Co}\left(\mathrm{NO}_{3}\right)_{2}$. $6 \mathrm{H}_{2} \mathrm{O}$ was dissolved in DI water. Solution stirred $15 \mathrm{~min}$ far the sake of proper dissolution purpose. $1 \mathrm{M} \mathrm{NaOH}$ solution was added after that up to $\mathrm{pH}$ became 10 and because of this solution clour became some what greenish blue. After 2 hour stirring precipited particles were separated using centrifuse. Wahsed this particles with DI water and Ethanol three four time. And this particle were transferred to oven at $65^{\circ} \mathrm{C}$ about 8 hour for drying purpose. In this way we got $\mathrm{Ni} . \mathrm{Co}(\mathrm{OH})_{2}$ powder.

\section{B. Characterization:}

The structure and lattice constant information of prepared sample was obtained by using Powder X-Ray Diffraction (PXRD) pattern using a Philips powder diffractometer PW3050/60. The measurement was performed by using 40 $\mathrm{kV}, 30 \mathrm{~mA}$ graphite filtared $\mathrm{Cu}-\mathrm{Ka}$ radiation $(\Lambda=1.54060$ $\dot{A})$. To testify topography of obtained materials, SEM and AFM of samples were observed using 3400N SEM and Asylum Research MPF3D respectively. The electrochemical experiments were carried out using an Eco-Chemie (The Netherlands) make electrochemical system Autolab PGSTAT 100 running with GPES (General Purpose Electrochemical System) version 4.9, software. Cyclic voltammetric and impedance experiments were carried at room temperature $\left(25^{\circ} \mathrm{C}\right)$ in a threeelectrode cell set up. The working electrode was carbon paste electrode with $2 \mathrm{~mm}$ diameter. Carbon paste made from spectroscopic grade carbon powder and silicon oil was mixed thoroughly using mortar and pestle with the supercapacitor materials (oxides and hydroxides of cobalt and nickel) material at 1:1 ratio forming homogeneous mixture with carbon paste. Saturated calomel (SCE) was used as a reference electrode and platinum wire was used as the counter electrode. All general chemicals used in the present study are of analytical-reagent grade. Nano pure water was used in all the experiments and also for the washing of the electrochemical cell set up.

\section{RESULT AND DISCUSSION}

Figure 1(a) shows the XRD patterns of the as-synthesized $\mathrm{Ni}(\mathrm{OH})_{2}, \quad \mathrm{Co}(\mathrm{OH})_{2}$ and $\mathrm{Ni} . \mathrm{Co}(\mathrm{OH})_{2}$ materials. The diffractions at the $2 \theta$ values of $19.77^{\circ}, 33.36^{\circ}, 38.83^{\circ}$, $52.59^{\circ}$, and $62.97^{0}$ in Fig. 1A are typical for the hexagonal phase of $\mathrm{Ni}(\mathrm{OH})_{2}$ (JCPDS: 14-0117) and indexed to the
(001), (100), (101), (102), (110) and (111) planes, respectively, ${ }^{4}$ confirming the formation of $\beta-\mathrm{Ni}(\mathrm{OH})_{2}$. Reflection peaks at the $2 \theta$ values $19.27^{\circ}, 31.65^{\circ}$, $37.12^{0}, 45.09^{0}, 59.64^{0}$ and $65.6^{0}$ shown in Figure $1(\mathrm{~b})$ are attributed to the $\mathrm{Co}(\mathrm{OH})_{2}$ material.

From fig 1 (c) it is clearly shown than reflection peaks at angle $11.14^{\circ}, 19.35^{\circ}, 38.49^{\circ}$, and $51.92^{\circ}$ corresponding to plane (003), (001), (101) and (102) and shifting the peaks confirms that substitution of Co in nickel hydroxide. The low intensity and broad diffraction peaks that material is nanocrystalline and which good for supercapacitor application because proton can easily permeate through the bulk of $\mathrm{Ni}(\mathrm{OH})_{2}$ material.

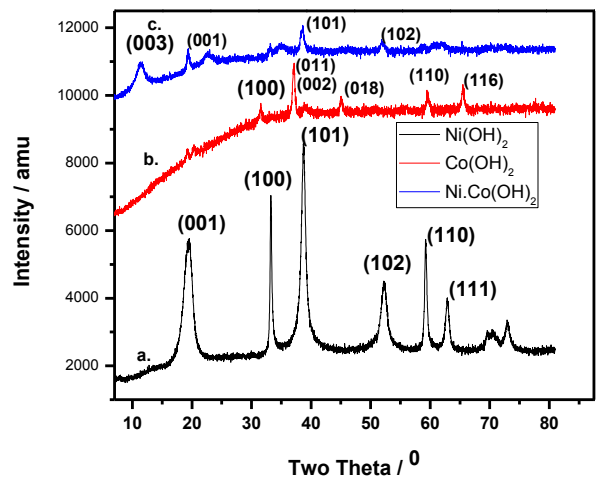

Figure I. The XRD pattern of the as synthesized $\beta$ $\mathrm{Ni}(\mathrm{OH})_{2}, \mathrm{Co}(\mathrm{OH})_{2}$ and $\mathrm{Ni} . \mathrm{Co}(\mathrm{OH})_{2}$

AFM characterization it is justified that morphology and height measurement of the $\mathrm{Ni}(\mathrm{OH})_{2}$, $\mathrm{Co}(\mathrm{OH})_{2}$ and $\mathrm{Ni} . \mathrm{Co}(\mathrm{OH})_{2}$ materials. As shown in figure 2 (a), (b) and (c) distribution of particles is very good in case of Ni.Co(OH $)_{2}$ Fig. 2 (d), (e) and (f) shows 3D view of the AFM image of $\mathrm{Ni}(\mathrm{OH})_{2}, \mathrm{Co}(\mathrm{OH})_{2}$ and $\mathrm{Ni} . \mathrm{Co}(\mathrm{OH})_{2}$.

Morphology and microstructure of samples was observed using Field Emission Scanning electron micrographs (FESEM). FESEM at a high magnification for hexagonal and nanosheet $\mathrm{Ni}(\mathrm{OH})_{2}$ shown in Figure 6.3(a). Particles formed is a hexagonal shape for $\beta$ $\mathrm{Ni}(\mathrm{OH})_{2}$ while in case of modified $\mathrm{Co}(\mathrm{OH})_{2}$ spherical shape like nanosheets. $\mathrm{Ni} . \mathrm{Co}(\mathrm{OH}) 2$ forming flower leaf like structure interconnected each other.

(Figure 6.3 (c)) forming porous structure. FTIR (Fourier transform infrared spectroscopy) results show various peaks in figure 6.4(a) and (b) for $\beta-\mathrm{Ni}(\mathrm{OH})_{2}$, $\mathrm{Co}(\mathrm{OH}) 2$ and $\mathrm{Ni} . \mathrm{Co}(\mathrm{OH})_{2}$, peaks between 500 and 750 $\mathrm{cm}^{-1}$ confirms the presence of metal hydroxide stretching.

In all cases the sharp peak at $3636 \mathrm{~cm}^{-1}$ is assigned to the stretching vibration mode $(\gamma \mathrm{OH})$ of non hydrogen bonded hydroxyl group in hydroxide.

The symmetric and antisymmetric stretching of carbonate anions present in the interlayer space of $\mathrm{Ni}(\mathrm{OH})_{2}$ is exhibited at 1630 and $1381 \mathrm{~cm}^{-1}$ respectively. S-O stretching peak shown at $1051 \mathrm{~cm}^{-1}$ in case of $\mathrm{Ni} . \mathrm{Co}(\mathrm{OH})_{2}$, which is absent in $\beta-\mathrm{Ni}(\mathrm{OH})_{2}$ and $\mathrm{Co}(\mathrm{OH})_{2}$. 

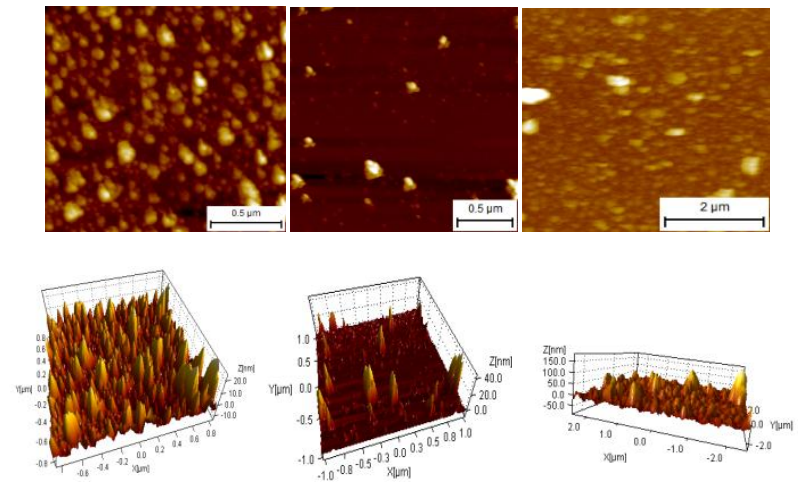

Figure II. The AFM image for a) $\beta$ - $\mathrm{Ni}(\mathrm{OH})_{2}$ b) $\mathrm{Co}(\mathrm{OH})_{2}$ c) $\mathrm{Ni} . \mathrm{Co}(\mathrm{OH})_{2}$
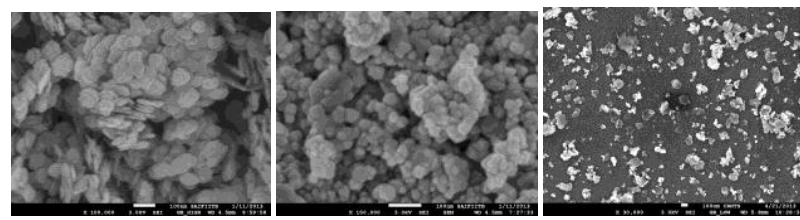

Figure III. The FESEM image of a) $\beta-\mathrm{Ni}(\mathrm{OH})_{2}$ b) $\left.\mathrm{Co}(\mathrm{OH})_{2} \mathrm{c}\right) \mathrm{Ni} \cdot \mathrm{Co}(\mathrm{OH})_{2}$.

TG and DTA curve shown in figure 6.5 describe properties of material as change with temperature. There are two stages of mass loss for both samples. The first thermogravimatric step represents the loss of adsorbed water or intercalated water.

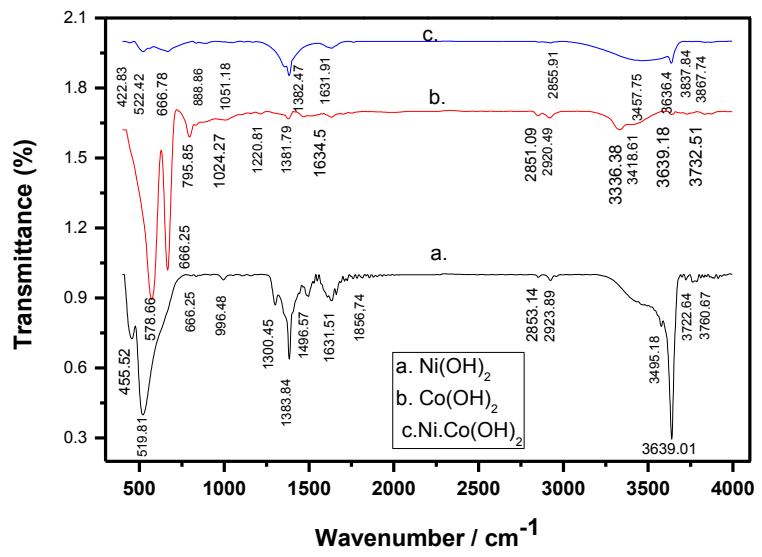

Figure IV. FTIR curves for a) $\beta-\mathrm{Ni}(\mathrm{OH})_{2}$ b) $\mathrm{Co}(\mathrm{OH})_{2}$ c) $\mathrm{Ni} . \mathrm{Co}(\mathrm{OH})_{2}$.

The mass loss at first stage is $18.33 \%, 4.52 \%$ and $23.265 \%$ for sample $\mathrm{Ni}(\mathrm{OH})_{2}, \mathrm{Co}(\mathrm{OH})_{2}$ and $\mathrm{Ni} . \mathrm{Co}(\mathrm{OH})_{2}$. Second stage corresponding to the decomposition of hydroxide to oxide emerged at $350^{\circ} \mathrm{C}, 350^{\circ} \mathrm{C}$ and $400^{\circ} \mathrm{C}$ and mass loss is $4.128 \%, 1.352 \%$ and $6.944 \%$.

In DTA analysis $\mathrm{Ni}(\mathrm{OH})_{2}$ showed only one peak at $284.54^{\circ} \mathrm{C}$ giving $236.1 \mathrm{~J}$ energy while in case of $\mathrm{Co}(\mathrm{OH})_{2}$ showed two exothermic peaks at $219.72{ }^{\circ} \mathrm{C}$ and $304.45^{\circ} \mathrm{C}$ took energy $77.44 \mathrm{~J}$ and $21.42 \mathrm{~J}$. $\mathrm{Ni} . \mathrm{Co}(\mathrm{OH})_{2}$ exhibited three peaks one endothermic at $272.27^{\circ} \mathrm{C}$ gave energy $618.7 \mathrm{~J}$ and two exothermic at $545.27^{\circ} \mathrm{C}$ and $767.71^{\circ} \mathrm{C}$ took $3538 \mathrm{~J}$ and $26.24 \mathrm{~J}$ energy.
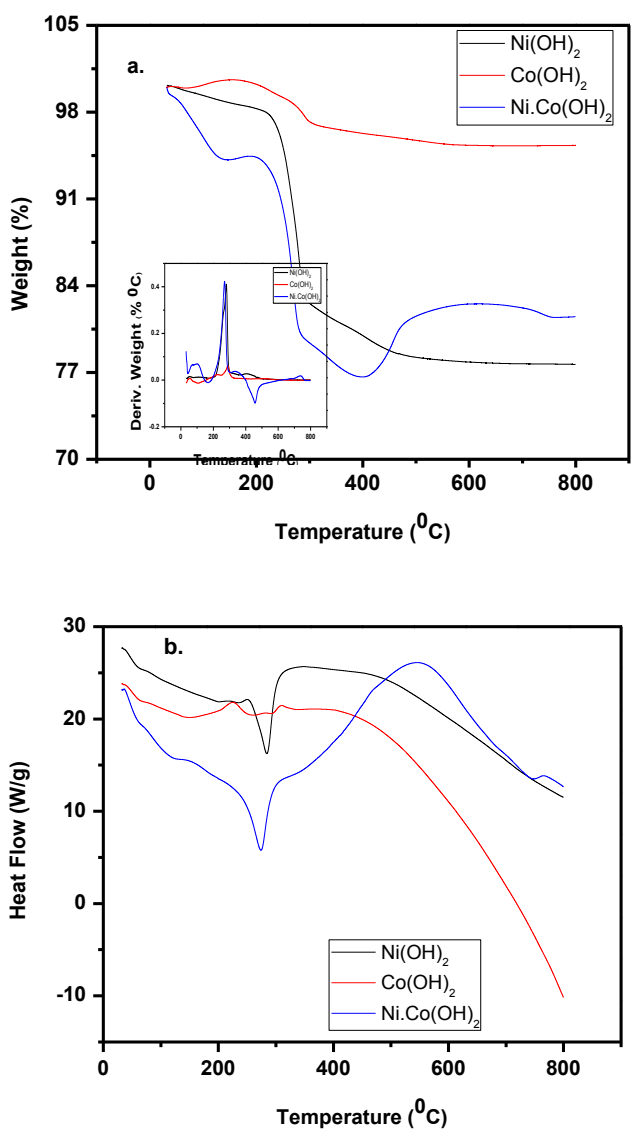

Fig. V a. TG b. DTA analysis of $\mathrm{Ni}(\mathrm{OH})_{2}, \mathrm{Co}(\mathrm{OH}) 2$ and $\mathrm{Ni} . \mathrm{Co}(\mathrm{OH})_{2}$.

In electrochemical characterization figure 6 (a) and (c) shows the $\mathrm{CV}$ curves of $\mathrm{Ni}(\mathrm{OH})_{2}, \mathrm{Co}(\mathrm{OH})_{2}$ and $\mathrm{Ni.} \mathrm{Co}(\mathrm{OH})_{2}$ in $1 \mathrm{M} \mathrm{KOH}$ solution at the scan rate $1,5,10$, $50,100,200,300,400$ and $500 \mathrm{mV} / \mathrm{s}$. The specific capacitance calculated at scan rate $1 \mathrm{mV} / \mathrm{s}$ is $20 \mathrm{o} \mathrm{F} / \mathrm{g}, 512$ $\mathrm{F} / \mathrm{g}$ and $708 \mathrm{~F} / \mathrm{g}$ for $\mathrm{Ni}(\mathrm{OH})_{2}, \mathrm{Co}(\mathrm{OH})_{2}$ and $\mathrm{Ni} . \mathrm{Co}(\mathrm{OH})_{2}$ respectively.
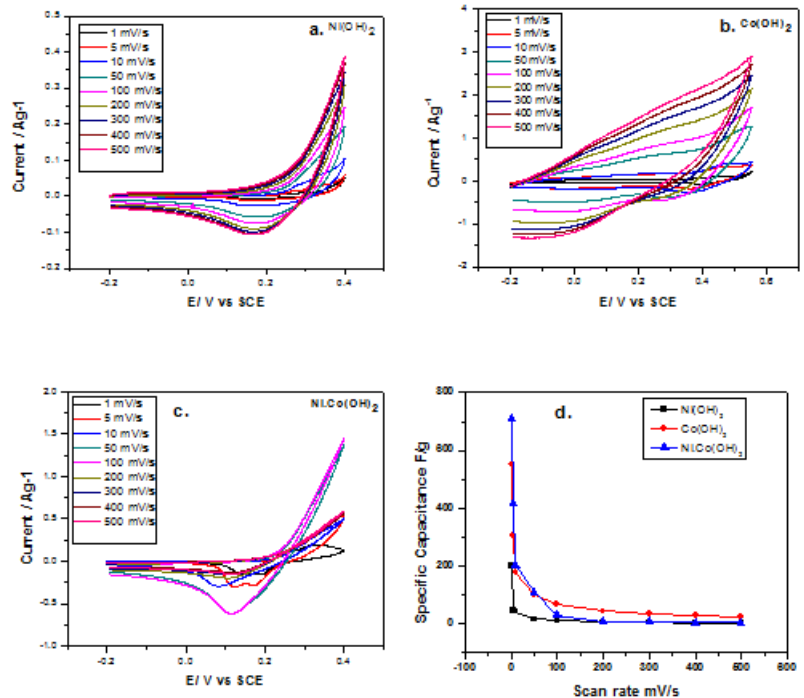

Figure VI. CV curve for a. $\mathrm{Ni}(\mathrm{OH})_{2}$, b. $\mathrm{Co}(\mathrm{OH})_{2}$ and c. $\mathrm{Ni} . \mathrm{Co}(\mathrm{OH})_{2}$ at Scan rate 1, 5, 10, 50, 100, 200, 300, 400 and $500 \mathrm{mV} / \mathrm{s} \mathrm{d}$. Variation of specific capacitance vs scan rate. 
From the above result it is clear that because of addition of cobalt in nickel hydroxide specific capacitance increases significantly. As shown in figure 6 b) and d) $\beta$ $\mathrm{Ni}(\mathrm{OH})_{2}$ and $\mathrm{Ni} . \mathrm{Co}(\mathrm{OH})_{2}$ electrode exhibits decreasing specific capacitance as scan rate goes in increasing. The electrochemical impedance spectra (EIS) clear electrodes charge transfer process. Semicircle in the high frequency region is related to the charge transfer process, and its diameter is charge -transfer resistance. In the middle frequency region, it displays a spike characteristic of capacitive behavior. Figure 7 shows Nyquist plots for $\mathrm{Ni}(\mathrm{OH})_{2}, \quad \mathrm{Co}(\mathrm{OH})_{2}$ and hybid $\mathrm{Ni} . \mathrm{Co}(\mathrm{OH})_{2}$ of this material.It can be seen that low frequency tail for the three samples is different. Hybid sample showing nearly vertical line, indicating a higher electron mobility, owing to broader interlayer space. Minor induction loop at the low frequency region are also indicative of the porous nature of the material.
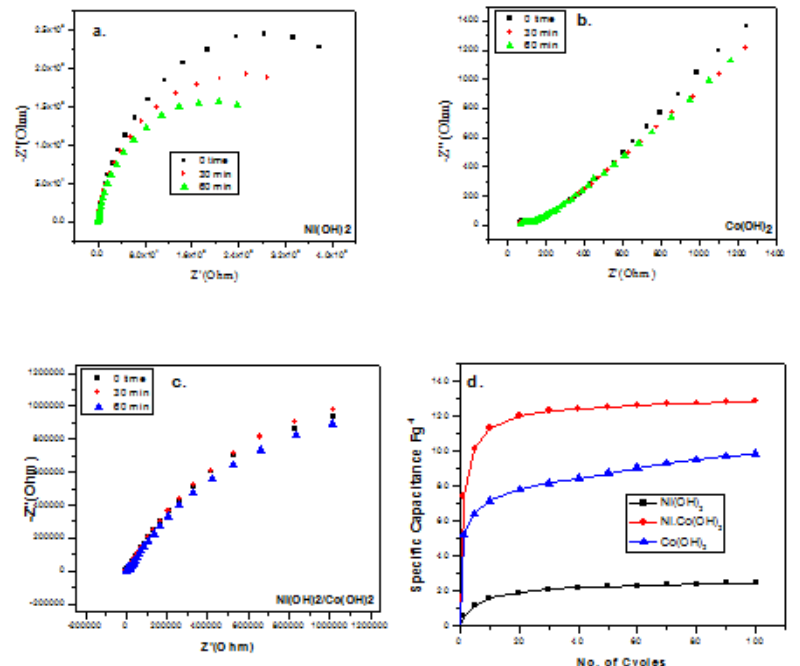

Figure VII. Nyquist plot for a. $\mathrm{Ni}(\mathrm{OH})_{2}$, b. $\mathrm{Co}(\mathrm{OH})_{2}$ and c. $\mathrm{Ni.Co}(\mathrm{OH})_{2}$ d. Cyclic stability of . $\mathrm{Ni}(\mathrm{OH})_{2}, \mathrm{Co}(\mathrm{OH})_{2}$ and Ni.Co $(\mathrm{OH})_{2}$

\section{CONCLUSION}

$\mathrm{Ni}(\mathrm{OH})_{2}$ plays an important role in supercapacitor application because of its theoretical high capacitance and low cost. And this theoretical capacitance can be achieved by doping other transition metals like cobalt. XRD result and FTIR (3636 $\mathrm{cm}^{-1}$ peak) confirm substitution of cobalt in nickel hydroxide. SEM revels that hexagonal shape of nanoparticals for $\beta-\mathrm{Ni}(\mathrm{OH})_{2}, \mathrm{Co}(\mathrm{OH})_{2}$ and $\mathrm{Ni} . \mathrm{Co}(\mathrm{OH})_{2}$. From cyclic voltammetric result specific capacitance of Ni.Co $(\mathrm{OH})_{2}$ gives a better capacitive performance than simple $\mathrm{Ni}(\mathrm{OH})_{2}$ and $\mathrm{Co}(\mathrm{OH})_{2}$ and which was $708 \mathrm{~F} / \mathrm{g}$. Also cyclic stability of $\mathrm{Ni} . \mathrm{Co}(\mathrm{OH}) 2$ is significantly improved.

\section{REFERENCES}

[1] Conway B. E. Electrochemical supercapacitors: scientific fundamentals and technological applications. Kluwer Academic, 2009, New York

[2] Burke A. J. Power Source, 2000, 91, 37-50.

[3] Korz K; Carlen M. Electrochim Acta, 2000, 45, 2483-2498.

[4] Saranpani S; Tilak B. V.; Chen C. P. J. Electrochem Soc, 1996, 143, 3791-3799.

[5] Frackowiak E. F. Carbon 2001, 39, 937-941.
[6] S. Y. YangS. Y.; Chang K. H.; Tien H. W.; Lee Y. F.; Lee S. M.; Wang Y. S. J. Meter. Chem. 2011, 21, 2374-2379.

[7] B. E. Conway, V. Birss, J. Wojtowicz, J. Power Sources 1997, 66, $1-8$.

[8] H. Lee, V. Manivannan, G. B. Googenough, C. R. Acad. Sci. Ser. II 1999, 2, 565-570.

[9] L. Su, L. Gong, J. Gao, J. Power Sources 2012, 209, 141-146.

[10] H. Kim, B. N. Popov, J. Power Sources, 2002, 104, 52-61.

[11] J. H. Zhong, A. L. Wang, G. R. Li, J. W. Wang, Y. N. Ou, Y. X. Tong, J. meter. Chem., 2012, 22, 5656-5665.

[12] J. Li, M. Wang, J. Wei, Z. Zhou, Nanoscale, 2012, 4, 4498-4503.

[13] X. H. Xia, J. P. Tu, Y. Q. Zhang, Y. J. Mai, X. L. Wang, C. D. Gu, X. B. Zhao, J. Phys Chem C, 2011, 115, 22662-22668.

[14] A. Audemer, A. Delahaye, R. Farhi, N. Sac Epee, J. M. Terascon, , J. Electrochem. Soc. 1997, 144, 2614-2620.

[15] M. Vidotti, C. V. Greco, E. A. Punzio, S. C. Torresi, Electrochemistry Commun. 8, 2006, 554-560.

[16] L. Su, L. Gong, J. Gao, J. Power Sources, 209, 2012, 141-146. 